\title{
The Dispute Settlement over the Ownership of a Double Certificates in Cirebon District Land Office
}

\author{
Bayu Nuraulia ${ }^{1}$, I Nengah Sugiarta ${ }^{2}$ and Djauhari ${ }^{3}$
}

Abstract. Birth of the Law of the Republic of Indonesia Number 5 of 1960 on Basic Regulation of Agrarian (BAL) has brought about significant changes in the world Indonesian land. BAL and a set of implementation regulations are expected to provide legal guarantees for the rights holders on the ground. But in fact the land can not be separated from problems, one of which occurred in Cirebon is the emergence of multiple certificate which led to the dispute. Here will be explained the factors that led to the emergence of a double and a certificate of completion method of dispute. To the authors do research with sociological juridical approach that combines literary and legal material facts obtained in the field through interviews. From these studies obtained answers that the emergence of double certificates can occur due to external factors and internal factors. For that matter, BPN trying to find a way out with the mediation. But if it does not receive the meeting point, the parties can file a lawsuit in court.

Keywords: Dispute; Double certificates.

\section{Introduction}

Birth of the Law of the Republic of Indonesia Number 5 of 1960 on Basic Regulation of Agrarian (BAL) on 24 September 1960 to early milestone reforms in agrarian and land in Indonesia, so it's make impact on the abandonment of policies in the Dutch colonial era. BAL calls for reform in the field of agrarian and land. The existence of BAL replace Wet Agrarische 1870 on verclaring domain known as the principle which states that all the colonies that can not be substantiated by proof of legal ownership west, the land is declared as belonging to the State/Dutch colonizers.

Interest enactment of BAL itself, as contained in the General Explanation of the BAL, namely:

- Laying the groundwork for the formulation of the National Agrarian law, which is a tool to bring prosperity, happiness and justice for the state and the farmer, in the framework of a just and prosperous society;

- Laying the groundwork to hold unity and simplicity in land law;

- Laying the groundwork to provide legal certainty regarding the rights to the land for the people of the whole

BAL give responsibility to the government to make land registration, in accordance with Article 19 BAL aimed at ensuring legal certainty include: ${ }^{4}$

- Certainty about the person / legal entity that owns the rights to land also called the certainty of the subject land rights bag;

- The certainty of the location, its limits, the length and width of the so-called object certainty over land.

\footnotetext{
${ }^{1}$ Students of Master of Notarial Law, Faculty Of Law, Universitas Islam Sultan Agung and SOE employee of PT. Bank Negara Indonesia (Persero) Tbk. Email nurauliabayu@gmail.com

2 Students of Master of Law, Faculty Of Law, Universitas Islam Sultan Agung email blinengah18@gmail.com

${ }_{3}^{3}$ Faculty of Law Universitas Islam Sultan Agung

${ }^{4}$ Irwan Soerodjo, 2003, Kepastian Hukum Hak Tas Tanah Di Indonesia, Arkota, Surabaya, p. 78.
} 
Article 1 Paragraph (1) of the Government of the Republic of Indonesia Number 4 of 1997 on Land Registration mention that land registration is suit activities carried out by the Government continuously, continuous and regularly, includes collecting, processing, accounting, and presentation as well as the maintenance of physical data and juridical, in the form of maps and lists, on plots and units of flats, including the granting of rights letter of receipt for parcels of land that the existing rights and ownership of the apartment units as well as certain rights which encumber.

With the BAL and a set of implementation regulations are expected to provide a legal guarantee to the holders of the rights to land in the entire territory of Indonesia. If we connect with the efforts of the government in the framework of the realignment of use, control and ownership of land, the registration of land rights is an important means for the realization of the rule of law throughout the territory of the Republic of Indonesia and also participated in the realignment using and ownership of land. ${ }^{5}$

Article 4 Paragraph (1) of the Government of the Republic of Indonesia Number 4 of 1997 on Land Registration mention that to provide certainty and legal protection as defined in Article 3 letter a to the holder of the rights over the land granted certificates of land rights. According to Article 1 Paragraph (20) of Government Regulation of the Republic of Indonesia Number 4 of 1997 on Land Registration, certificate is proof of the rights referred to in Article 19 paragraph (2) c BAL for land rights, property rights, land endowments, ownership of the apartment units and mortgages respectively has been recorded in the land book

The certificates represent authentic proof equipment. The strength of the certificate is a legal guarantee for holders of the certificate as evidence that perfect long as no opponent who proves otherwise. A person or legal entity will be easy to prove himself as the holder of rights to a plot as well as the state of the soil, for example spacious, boundaries, buildings, along with the right kind of loads that exist on land rights, and so on. ${ }^{6}$

Along the way, though the certificate of land rights is a perfect evidence, but still, in reality it can not guarantee certificate is spared the trouble. One example of the problems in the field of land is happening in Cirebon relating to proof of ownership is a double certificates.

Double certificates that piece of land that has more than one certificate. ${ }^{7}$ Double certificates can caused by their false certificates. Generally the fake certificates made on land that is empty and has a high value that using the old certificate blank. Counterfeiting occurs because the certificate is not based on the right pedestal rights, such as the issuance of certificates that are not based on the bottom right of the right, such as issuing certificates based on the certificate of ownership falsified. Other forms a rubber stamp forgery BPN and land records. ${ }^{8}$

Based on the background, as mentioned above, it can be formulated legal issues relating to the research, are as follows: What are the factors that cause a double certificates in Cirebon District Land Office? How is the settlement of disputes over the ownership of a double certificates in Cirebon District Land Office?

\section{Research methods}

5 Bachtiar Effendie, 1993, Pendaftaran Tanah di Indonesia dan Peraturan-Peraturan Pelaksanaannya, Alumni, Bandung, p. 5.

${ }^{6}$ Andrian Sutedi, 2011, Sertifikat Hak Atas Tanah, Sinar Grafika, Jakarta, p. 1.

${ }^{7}$ Soni Harsono, 1992, Kegunaan Sertifikat dan Permasalahannya, Seminar Nasional, Yogyakarta, p. 6.

${ }^{8}$ Ali Achmad Chomzah, 2002, Hukum Pertanahan (Cet. I), Prestasi Pustaka, Jakarta, p. 137 
Authors conducted a study using sociological juridical approach that combines legal material literature such as books, legislation, and materials other laws related to this study to obtain secondary data which is then connected with the facts obtained in the field through interviews Employees directly to the Notary and the National Land Agency Cirebon to obtain primary data.

\section{Discussion}

\subsection{Factors that Cause Double certificates in Cirebon District Land Office}

Disputes can happen anytime, anywhere and to anyone. Disputes can occur between individuals with the individual, the individual with the group, the group with the group. The wide range of understanding of the dispute were:

- According to Indonesian dictionary, the dispute is a disagreement or conflict. Conflict means that their opposition or disagreement among people, groups or organizations against an object problems

- According Winardi, the dispute is a disagreement or conflict between individuals or groups that have the same relationship or interest on an object of ownership, which creates legal effect between one another. ${ }^{9}$

- According to the Takdir Rahmadi, conflict or dispute the circumstances in which people experience each Factual disputes and disagreements that exist on them only. ${ }^{10}$

- According to Ali Ahmad Chomzah, the dispute is between two or more parties that originated from a different perception of an interest or property which may give rise to legal consequences for both. ${ }^{11}$

- Article 1 Paragraph (1) of the Regulation of the Minister of State for Agrarian Affairs / Head of National Land Agency Number 1 of 1999 on the Procedures for Handling Dispute explained understanding of land disputes are differences of opinion on the validity of rights, land titling, registration of land rights, including transition and publishing proof of its right, between the interested parties and between the parties concerned with the environment agencies of the National Land Agency.

- According Sarjita, land disputes are disputes between two or more parties that feel or the aggrieved parties to use and control their land rights, are resolved through consensus or through the courts. ${ }^{12}$

One cause land dispute that is double certificates. Double certificates is a the certificate outlining in the same plot. So therefore, the plot described by two or more different certificate data. It is usually named after the certificate overlap, both overlap the entire field, and the overlapping portion than the land. ${ }^{13}$

This double certificates occurs because the certificate is not mapped, the land registry or map of the regional situation. If the land registration maps or map the situation in

\footnotetext{
${ }^{9}$ Winardi, 2007, Managemen Konflik (Konflik Perubahan dan Pengembangan), Mandar Maju, Bandung, p. 1.

10 Takdir Rahmadi, 2011, Mediasi Penyelesaian Sengketa Melalui Pendekatan Mufakat, Rajawali Pers, Jakarta, p. 1.

${ }^{11}$ Ali Ahmad Chomzah, 2003, Seri Hukum Pertanahan III Penyelesaian Sengketa Hak Atas Tanah dan Seri Hukum Pertanahan IV Pengadaan Tanah Instansi Pemerintah, Prestasi Pustaka, Jakarta, p. 14.

12 Sarjita, 2005, Teknik dan Strategi Penyelesaian Sengketa Pertanahan, Tugujogja Pustaka, Yogyakarta, p. 8.

${ }^{13}$ Ali Ahmad Chomzah, Op. Cit, p. 139.
} 
any office or drawn Land made and the situation / measurement certificate made in the map, then the likelihood of a double certificates will be small. ${ }^{14}$

Double certificates generally occur on land that is empty and has not been built. The emergence of double certificates are caused by some of the following: ${ }^{15}$

- When measurements or research field, the applicant intentionally or unintentionally shows the lay of the land and land boundaries were wrong.

- The existence proof or recognition of the rights which proved to contain untruth, falsehood or no longer valid.

- For the area concerned is not yet available land registry map.

Based on interviews with employees of Cirebon District Land Office, the emergence of double certificates could be due to the following factors:

- The existence of bad faith of the applicant's certificate which aims to find the clappers, where the applicant provides false data or inconsistent with the facts in the field

- Their inheritance disputes

- No maintenance of well over land boundaries

- An error on the part of the Land Office in data processing of physical and juridical, namely in the measurement and mapping of the object as well as the lack of carefully situations Party Land Office in issuing land certificates are documents that form the basis for the issuance of the certificate is not examined closely, which may be documents not meet the requirements as specified by the provisions of the applicable law.

- The absence of land registration map of the region

- The object of land that is not controlled by the legitimate owner of the land which has long been abandoned

- The lack of functioning village officials so that there are opportunities for misuse in the sense of not carrying out the duties and responsibilities properly

- The village government / village that has no ground data

\subsection{How to Dispute Over The Ownership Of A Double certificates in Cirebon District Land Office}

Article 1 Paragraph (1) The Supreme Court Regulation No. 1 of 2016 on Mediation Procedure of the Court states that the Mediation is a way of settling disputes through negotiation process to obtain the agreement of the Parties with the assistance of Mediator.

Munir Fuady explained that mediation is a process of negotiation to solve the problem through outside parties who are impartial and neutral that will work with the parties to help find a solution to resolve the dispute satisfactorily for both parties. Third party to help resolve the dispute referred to a mediator. Mediator does not have the authority to give its ruling on the dispute, but only serves to help and find solutions to the disputing parties. Experience, ability and integrity of the mediator is expected to streamline the process of negotiation between the parties to the dispute. ${ }^{16}$ Mediation

14 Supranowo, 1992, Sertifikat dan Permasalahannya, Makalah pada Seminar Nasional "Kegunaan Sertipikat dan Permasalahannya", Yogyakarta p. 8.

${ }^{15}$ Ali Ahmad Chomzah, Op. Cit, p. 139.

${ }^{16}$ Munir Fuady, 2000, Arbitrase Nasional, Alternatif Penyelesaian Sengketa Bisnis, Citra Aditya Bakti, Bandung, p. 47. 
through a system compromise between the parties, while third parties who are acting as a mediator only as a helper and facilitator. ${ }^{17}$

Based on interviews with the staff of the Land Board Cirebon, procedures for settling disputes over land in the District Land Office Cirebon begins with a complaint written by the applicant to the Administration, and then the Administration make a recommendation letter to the Head of the Land Office, addressed to the Section of Dispute Conflict as a mediator to then file a complaint examined. After the complaint files reviewed, then made the call both parties to the dispute, for further mediation in order to achieve common ground. Following an agreement of the parties to mediation, the mediator make an official report on the implementation of the mediation. After the news event is made, then the mediator will conduct mediation with the parties to the dispute. If the parties to the dispute agree with the decision of the given mediator, then the decision will be followed up by the dispute settlement itself. But in case the parties to the dispute does not come to fruition, then allowed to settle the dispute in court.

\section{Closing}

\subsection{Conclusion}

- The emergence of double certificates may occur or be caused by two factors, namely internal factors where there is an administrative error of the Land Office in the collection and processing of physical data or due to external factors, namely the intention of the applicant because the applicant shows possession limit is wrong, and so on.

- There are two alternative dispute resolution on double certificates that mediation, court. Basically the settlement of land disputes through mediation first attempting between disputing parties to achieve a win-win solution. If after mediation still not found common ground among the parties to the dispute, the parties can continue the settlement of disputes through the lawsuit in court.

\subsection{Suggestion}

So that the problem does not happen again on double certificates or can be minimized, it is necessary legal counseling to the public of the importance of orderly administration land so that the data of land in the office will be updated. In addition, the government is expected to more frequently hold a National Program in order to create the orderly administration bleaching Land field. In addition to this, the Land Office is expected to be able to provide internal controls so that no error in the admission file and inputting soil data that will hurt many parties.

\section{References}

\section{Books}

[1] Ali Achmad Chomzah, 2002, Hukum Pertanahan (Cet. I), Prestasi Pustaka, Jakarta.

[2] Ali Achmad Chomzah, 2003, Seri Hukum Pertanahan III Penyelesaian Sengketa Hak Atas Tanah dan Seri Hukum Pertanahan IV Pengadaan Tanah Instansi Pemerintah, Prestasi Pustaka, Jakarta

17 Yahya Harahap, 2009, Hukum Acara Perdata Tentang Gugatan, Persidangan, Penyitaan, Pembuktian dan Putusan Pengadilan, Sinar Grafika, Jakarta, p. 233. 
[3] Andrian Sutedi, 2011, Sertifikat Hak Atas Tanah, Sinar Grafika, Jakarta.

[4] Bachtiar Effendie, 1993, Pendaftaran Tanah di Indonesia dan PeraturanPeraturan Pelaksanaannya, Alumni, Bandung.

[5] Irwan Soerodjo, 2003, Kepastian Hukum Hak Tas Tanah Di Indonesia, Arkota, Surabaya.

[6] Munir Fuady, 2000, Arbitrase Nasional, Alternatif Penyelesaian Sengketa Bisnis, Citra Aditya Bakti, Bandung.

[7] Soni Harsono, 1992, Kegunaan Sertifikat dan Permasalahannya, Seminar Nasional, Yogyakarta.

[8] Takdir Rahmadi, 2011, Mediasi Penyelesaian Sengketa Melalui Pendekatan Mufakat, Rajawali Pers, Jakarta.

[9] Winardi, 2007, Managemen Konflik (Konflik Perubahan dan Pengembangan), Mandar Maju, Bandung.

[10] Yahya Harahap, 2009, Hukum Acara Perdata Tentang Gugatan, Persidangan, Penyitaan, Pembuktian dan Putusan Pengadilan, Sinar Grafika, Jakarta.

\section{Laws and regulations}

[1] Law of the Republic of Indonesia Number 5 of 1960 on Basic Regulation of Agrarian (BAL)

[2] Minister of State for Agrarian Affairs / Head of National Land Agency Number 1 of 1999 on the Procedures for Handling Dispute

[3] Indonesian Government Regulation No. 4 of 1997 on Land Registration 